\title{
Assessment of Health Risk of Bromate in Ozonised Bottled and Sachet Water in Aba Metropolis, South Eastern Nigeria
}

Irogbeyi Longinus Amarachi ${ }^{1 *}$, Nweke Ifeoma Nneka ${ }^{1}$, Akuodor Godwin Christian ${ }^{2}$, Orji Chima Ernest ${ }^{2}$, Ekenjoku John Azubuike ${ }^{1}$, Ezejiofor, Tobias Innocent Ndubuisi ${ }^{3}$, Cajetan Elo $\mathrm{Ilo}^{2}$

${ }^{1}$ Department of Pharmacology and Therapeutics, Abia State University, Uturu, Nigeria

${ }^{2}$ Department of Pharmacology and Therapeutics, Faculty of Medicine, NnamdiAzikiwe University, Nnewi Campus, Nigeria

${ }^{3}$ Department of Biotechnology, School of Biological Sciences, Federal University of Technology, Owerri, Nigeria

DOI: $10.36348 /$ SJMPS.2019.v05i10.009

| Received: 07.10.2019 | Accepted: 14.10.2019 | Published: 27.10.2019

*Corresponding author: Irogbeyi, Longinus Amarachi

\section{Abstract}

The study was carried out to determine the bromate contents in popular commercially available different brands of bottled and sachet drinking water in Aba metropolis. To assess the health risk of bromate in ozonised bottled and sachet water in Aba metropolis, South Eastern Nigeria Bromate determination was done using spectrophotometric method after treatment of the samples and absorbance was measured at $530 \mathrm{~nm}$. The mean concentration of $\mathrm{BrO}_{3}{ }^{-}$in different brands of bottled water was found to be $4.09 \pm 0.44 \mu \mathrm{g} / 1$ (range: $3.48 \pm 0.50-4.98 \pm 0.79 \mu \mathrm{g} / \mathrm{l}$ ). On the other hand, the mean concentration of bromate ion in sachet water was $5.07 \pm 0.78 \mu \mathrm{g} / \mathrm{l}$ with range $3.15 \pm 0.26-6.33 \pm 0.78 \mu \mathrm{g} / \mathrm{l}$. Correlation analysis showed that bromate formation was influenced by the presence of bromide ions. There was a high cancer risk assessment resulting from the ingestion of bromate in bottled and sachet water which could occur overtime while both the drinking water were safe from the chemical toxicity risk point of view.

Keywords: Bromate, Cancer risk, chemical toxicity risk, Bottled water, sachet water, Nigeria.

Copyright @ 2019: This is an open-access article distributed under the terms of the Creative Commons Attribution license which permits unrestricted use, distribution, and reproduction in any medium for non-commercial use (NonCommercial, or CC-BY-NC) provided the original author and source are credited.

\section{INTRODUCTION}

Water Quality is determined by the concentration of biological, chemical and physical contaminants. A contaminant becomes a pollutant when it exceeds an acceptable concentration advised by WHO guidelines [1].Water quality standards have been developed to minimize known chemical and microbial risks.

Production of bottled and sachet water has become a local intervention in Nigeria where public drinking water supply is unreliable [2].This has resulted in people looking for alternative drinking water source sold in bottled and polythene sachet.

The sources of bottled and sachet water in Aba metropolis, Abia state, south east, Nigeria are mainly bore holes and well water. The common technique for preparation of bottled and sachet water is based on chlorination, ultra filtration, ozonisation methods, etc. which are itself the removal technique of bromide ion. In spite of applying the removal processes, trace quantities of bromide are found in water.

\section{Bromate}

Bromate is not commonly found in water, but it may be formed as a by-product of ozonation disinfection of drinking water and also as a contaminant introduced from treatment of water with concentrated hypochlorite [3, 4]. Thus, ozonation treatment of drinking water represents an important potential pathway of bromate formation. The drinking water disinfection processes of ozonation, and to a lesser extent, chlorination, can yield the bromate ion as an unintentional by-product of the disinfection reactions [5]. Ozonation has the desirable advantage of being able to control Cryptosporidium parvum [6]. Cryptosporidium is a zoonotic parasitic protozoan, and its oocysts are refractory to most disinfectant chemicals [7. It was found that bromate formation was affected by such water quality conditions as bromide concentration, $\mathrm{pH}$, temperature, carbonate alkalinity, ultraviolet light (UVA), disinfectant concentration and time (mg/l-min) and transferred ozone dose, among other factors. It was noted that even water with lower concentrations of bromide can approach the U.S. EPA standard of 10 microgram/litre $(\mu \mathrm{g} / \mathrm{l})$ for bromate [8] at sufficient ozone concentrations and disinfection times. Formation of bromate and haloamines after exposure to sunlight 
had been reported earlier in seawater to which chlorinated waste water had been discharged [9].

The U.S environmental Protection Agency (EPA) and European Commission have established a regulatory maximum contaminant level (MCL) of $10 \mu \mathrm{g} / \mathrm{l}$ bromate in drinking water [10]. Later, the European commission set a lower MCL of $3 \mu \mathrm{g} / \mathrm{l}$ bromate for natural mineral waters and spring waters treated by ozonation (11). The same value was proposed by the Drinking Water Commission European Union. More recently, WHO has proposed a guideline of $<0.5 \mu \mathrm{g} / 1[4]$.

The following equations show the pathway by which bromide $\left(\mathrm{Br}^{-}\right)$is oxidized by ozone to bromate $\left(\mathrm{BrO}_{3}{ }^{-}\right)$through the intermediate formation of hypobromite $\left(\mathrm{OBr}^{-}\right)$. These equations also show that ozone does not oxidize hypobromous acid ( $\mathrm{HOBr}$ ) to bromate. Since increased acid $\left(\mathrm{H}_{3} \mathrm{O}^{+}\right)$will favor the formation of hypobromous acid, this suggests that ozonation at a low $\mathrm{pH}$ will tend to minimize bromate formation [12].

$$
\begin{aligned}
& \mathrm{Br}^{-}+\mathrm{O}_{3}+\mathrm{H}_{2} \mathrm{O} \rightarrow \mathrm{HOBr}+\mathrm{O}_{2}+\mathrm{OH}^{-} \\
& \mathrm{HOBr}+\mathrm{H}_{2} \mathrm{O} \longrightarrow \mathrm{H}_{3} \mathrm{O}++0 \mathrm{Br}^{-} \\
& \mathrm{OBr}^{-}+2 \mathrm{O}_{3} \longrightarrow \mathrm{BrO}_{3}-+2 \mathrm{O}_{2} \\
& \mathrm{HOBr}+\mathrm{O}_{3} \rightarrow \text { No Reaction }
\end{aligned}
$$

\section{Guidelines Values}

Under the 1986 EPA guidelines for Carcinogen Risk Assessment [13] on the basis of adequate evidence of carcinogenicity in male and female rats, bromate was classified as a probable human carcinogen by the oral route of exposure. Data on the carcinogenicity of bromate via the inhalation route are inadequate for an assessment of its human carcinogenic potential. The IPCS [14] value of $0.1 \mu \mathrm{g} / \mathrm{kg}$ of body weight per day for a $10^{-5}$ excess lifetime cancer risk level was based on an increased incidence of renal tumours in male rats given potassium bromate in drinking-water for 2 years using the same study (15). The upper-bound estimate of the cancer potency for bromate is 0.19 per $\mathrm{mg} / \mathrm{kg}$ of body weight per day. The concentrations in drinking water associated with upperbound excess lifetime cancer risks of $10^{-4}, 10^{-5}$ and $10^{-6}$ are 20, 2 and $0.2 \mu \mathrm{g} / \mathrm{l}$, respectively [16]. Both the World Health Organization (WHO) and the U.S. Environmental Protection Agency (EPA) have judged bromate as a potential carcinogen, even at very low $\mu \mathrm{g} / \mathrm{l}$ levels. The U.S. EPA has estimated a potential cancer risk of $1 \times 10-4$ ( 1 in 104) for a lifetime exposure to drinking water containing bromate at $5 \mu \mathrm{g} / \mathrm{L}$ and recently issued new rules that require public water supplies to control previously unregulated microbes (e.g., cryptosporidium and giardia) and cancer-causing Disinfection Bye Products (DBPs) in finished drinking water. The U.S. EPA Maximum Contaminant Level Goal (MCLG) for bromate in drinking water is set at zero, based on carcinogenicity. The Maximum Contaminant Level (MCL) is set at $10 \mathrm{ppb}$, based on the Practical Quantification Limit (PQL) [3].

\section{MATERIALS AND METHODS Sample Collection and preparation}

Bottled and sachet water samples were purchased from the different designated areas that make up Aba metropolis, namely Aba North, Aba South and part of Osisioma. The number of bottled and sachet water used was 35 and 55 respectively of different brands purchased in triplicates all were written ozonised. The collected bottled and sachet water samples were filtered through $0.45 \mu$ filter paper, acidified with $0.01 \mathrm{M}$ of nitric acid and stored in a precleaned plastic bottle of $500 \mathrm{ml}$ capacity.

\section{Analytical Technique of Bromate Content of Water \\ Bromate content of bottled and sachet water samples was quantitatively analysed using previously reported method [17]. Drinking water samples were passed through a column of strong cationic resin, converted to the $\mathrm{Na}^{+}$form by treatment with saturated Nacl solution. Before use, the resin was washed with deionized water. The first $3 \mathrm{ml}$ of sample eluted from the column were discarded and then $25 \mathrm{ml}$ of sample were added with $1.5 \mathrm{ml}$ of $0.1 \mathrm{M} \mathrm{Hcl}, 1.25 \mathrm{ml}$ of citrate buffer solution and $0.2 \mathrm{ml}$ of colour reagent. After 30 min the absorbance was measured at $530 \mathrm{~nm}$. Blank samples in deionized water were treated in the same manner without passing through the cationic resin.}

\section{Analytical Technique of Bromide Content of Water} Procedure: Into a $50 \mathrm{~cm}^{3}$ water sample containing $0.005-1.0 \mathrm{mg}$ bromide were added $10 \mathrm{~cm}^{3}$ buffer solution and (dropwise) $5 \mathrm{~cm}^{3}$ hypochlorite reagent solution. The mixture was boiled for 10 minutes.

Then $2.5 \mathrm{~cm}^{3}$ of sodium formate solution was added and the sample boiled further for $5 \mathrm{~min}$. When it was cooled down it was transferred quantitatively into a $100 \mathrm{~cm}^{3}$ volumetric flask. $15 \mathrm{~cm}^{3}$ rosaniline solution was added and the mixture was homogenised. Three minutes, $25 \mathrm{~cm}^{3}$ t-butyl alcohol-water solvent mixture (specific density $0.8 \mathrm{~g} / \mathrm{cm}^{3}$ ) is added and the flask is filled to the mark. The absorbance is measured. Reagent is made in the same way, substituting the sample with distilled water and the absorbance difference between the sample and blank is used for evaluation. A calibration curve is prepared, plotting the absorbance measured against standard solution.

\section{Risk Assessment}

The excess cancer risk due to ingestion of bromate in bottled and sachet water was evaluated based on the general USEPA standard method (18). 


\section{Methodology of Excess Cancer Risk Assessment}

The individual excess cancer risk (IECR) as defined in USEPA, (18) can be defined by the following expression;

$\mathrm{IECR}=\mathrm{UR}_{\mathrm{o}} \mathrm{X} \mathrm{C}_{\mathrm{bw}}$-------- (equation (1)

Where $\mathrm{UR}_{0}$ is the risk factor expressed as $\left(\mathrm{Uq} . \mathrm{L}^{-1}\right)^{-1}$ due to ingestion of drinking water and the considered toxicological values by US EPA of inorganic bromate for the cancer risk calculation at the case-study area is $U R 0=2 \times 10-5(\mu \mathrm{g} \cdot \mathrm{L}-1)-1 . \mathrm{Cbw}$ giving the estimated concentration of bromate in bottled water and sachet water expressed as uq. $\mathrm{L}^{-1}$.

\section{Methodology of Chemical Risk Assessment}

To evaluate the hazard quotient for bromate, the chemical toxicity risk as life time average daily dose (LADD) was estimated with the help of equation 3 [18, $19,20]$ and was compared to the reference dose (RfD) of $0.372 \mathrm{q} / \mathrm{kg} /$ day which is calculated on the basis of maximum acceptable level of bromate $(10 \mu \mathrm{q} / \mathrm{l})$ in drinking water per guideline of US EPA [13]. Here the water ingestion rate was set as $2 \mathrm{~L}^{-d_{a y}}{ }^{-1}$ which is similar to the upper-bound level of adult daily intake recommended by USEPA [21], 365 for exposure frequency US EPA [20], 54.5 years for total exposure duration i.e the average all Nigeria life expectancy for both males and females [22], 19893 days for average time and $60.7 \mathrm{~kg}$ for body weight [23]. The hazard quotient (HQ) and chemical toxicity risk (LADD) was calculated through ingestion of bottled and sachet water by the following formula:



$\mathrm{Ci}=$ Concentration of bromate in bottled water $(\mu \mathrm{g} / \mathrm{l}$

$\mathrm{IR}=$ Ingestion rate (L/day)

$\mathrm{EF}=$ Exposure frequency (days/year)

LE $=$ Life expectancy (years)

$\mathrm{AT}=$ Average Time (days)

$\mathrm{BW}=$ Body Weight $(\mathrm{kg})$

$\mathrm{RfD}=$ Reference Dose $\left(\mu \mathrm{g} \cdot \mathrm{kg}^{-1} \cdot\right.$ day $\left.^{-1}\right)$

LADD $=$ Lifetime average daily dose,$\left.\left(\mu \mathrm{g} \cdot \mathrm{kg}^{-1} \cdot \mathrm{day}^{-1}\right)\right)$

\section{STATISTICAL ANALYSIS}

The results collected in this study area were expressed as mean $\pm \mathrm{SD}$. Results were compared using the one way ANOVA analysis and independent sample test. Statistical analysis was performed using SPSS (Version 20) and (Software version 8.1) At 5\% significant level, the calculated probability value was found to be lower than the tabulated value.

\section{RESULTS AND DISCUSSION}

\section{Parameters used to assess cancer risk and LADD in bottled and sachet water}

The bromate distribution can be assumed as a normal distribution. Ingestion rate of drinking water, total exposure duration and average time were considered as constant input values shown in table [1]

\section{Bromate and Bromide levels in Bottled and Sachet water}

The mean concentrations of $\mathrm{BrO}_{3}{ }^{-}$and $\mathrm{Br}^{-}$in different brands of packaged bottled water samples in Aba metropolis were found to be $4.09 \pm 0.44 \mu \mathrm{g} / \mathrm{l}$ (range: $3.48 \pm 0.50-4.98 \pm 0.79 \mu \mathrm{g} / \mathrm{l})$ and $9.11 \pm 1.86 \mu \mathrm{g} / \mathrm{l}$ (range: $6.51 \pm 0.69-11.45 \pm 0.82 \mu \mathrm{g} / \mathrm{l}$ ) respectively. On the other hand, the mean values of $\mathrm{BrO}_{3}^{-}$and $\mathrm{Br}^{-}$in different brands of packaged sachet water samples were expressed as follows; $5.07 \pm 0.78 \mu \mathrm{g} / \mathrm{l}$ (range: $3.15 \pm$ $0.26-6.33 \pm 0.78 \mu \mathrm{g} / \mathrm{l})$ and $10.90 \pm 1.0 \mu \mathrm{g} / \mathrm{l}$ (range:8.20 $\pm 0.79-12.37 \pm 0.91 \mu \mathrm{g} / \mathrm{l}$ ) respectively. The level of $\mathrm{BrO}_{3}{ }^{-}$content in bottled water found in this study was quite lower than the one cited in literatures in other country India with range $(6-65 \mu \mathrm{g} / \mathrm{l})(16)$. A wide margin of difference was obtained in Canada with the $\mathrm{BrO}_{3}{ }^{-}$range of $4.3-37.3 \mu \mathrm{g} / \mathrm{l}$ (20) coupled with a study in Los Angeles which has a wider margin of difference of $\mathrm{BrO}_{3}$ content of 60 - $90 \mu \mathrm{g} / \mathrm{l}$ [24]. No work has been reported so far on bromate level in sachet water in the country or outside of the country where it may be neglected.

The mean value of $\mathrm{BrO}_{3}^{-}$in sachet water $(5.07 \pm 0.78 \mu \mathrm{g} / \mathrm{l})$ was higher than the mean value of $4.09 \pm 0.44 \mu \mathrm{g} / \mathrm{l}$ of $\mathrm{BrO}_{3}{ }^{-}$found in bottled water in this study. It is noteworthy that the International Bottled Water Association (IBWA) based on USEPA has set a self- regulatory limit for bromate in bottled water of 10 $\mu \mathrm{g} / \mathrm{L}$ whereas the World Health Organization (WHO) have set a guideline value of $25 \mu \mathrm{g} / \mathrm{L}$ which is under review and the proposed new guideline value is $10 \mu \mathrm{g} / \mathrm{L}$ [16]. The mean ratio of measured $\mathrm{BrO}_{3}{ }^{-} / \mathrm{Br}^{-}$in bottled and sachet water in this study was found to be $0.48 \pm 0.03 \mu \mathrm{g} / \mathrm{l}$ and $0.46 \pm 0.02 \mu \mathrm{g} / \mathrm{l}$ respectively and these ratios are below the predicted ratios of 1.6, because it is derived that $62.5 \%(6.25 \mu \mathrm{g} / \mathrm{l})$ of bromide in bottled water is needed to convert into bromate upon ozonation to exceed the minimum contamination level of $10 \mu \mathrm{g} / \mathrm{l}$ [16]. 
The mean values of bromate formation against predicted concentration in bottled and sachet water were $28.73 \%$ and $29.11 \%$ respectively. These values were in agreement with the predicted concentration of $62.5 \%$ because none of the values of bromate ion concentration found in this study was above $10 \mu \mathrm{g} / \mathrm{l}$.

The measured bromate and bromide concentrations, their ratios and $\mathrm{PH}$ values in bottled and sachet water of various locations and consequently risks (Excess cancer risk and chemical toxicity risk) due to ingestion were shown in Table 2 and 3 respectively.

In the $\mathrm{Ph}$ range of 7-8, Haag and Hoigne [25] reported that only $1-10 \%$ of hypobromous acid ( $\mathrm{HOBr}$ ) total (in the form of hypobromite ion) takes part in reactions with molecular ozone and that the formation of hypobromous acid is very slow and does not contribute significantly to bromate formation.

This report confirmed the observation made in this study with the mean $\mathrm{Ph}$ value of $7.30 \pm 0.14$ and the range of $7.10 \pm 0.10-7.7 \pm 0.59$ in bottled water. The reduction in bromate level may be because of not favouring the formation of intermediate species as hypobromite $(\mathrm{OBr})$. This was also found in Indian bottled water which was slightly alkaline and varied within narrow range of 7.1-7.3 [16]. However, the slight increase in bromate level found in sachet water may be as a result of $\mathrm{Ph}$ range of $7.3 \pm 0.10-8.5 \pm 0.03$ with mean value of $7.7 \pm 0.32$ which was more alkaline.

\section{Correlations}

Pearson co-efficient of correlation (scatter plot) was used to establish a correlation of bromate and bromide contents in bottled and sachet water which showed a fairly high degree of correlation in fig 1 and 2 respectively. This implied that bromate contents in bottled and sachet water were much influenced and controlled by bromide content.

Figure 3 was the scatter plot showing the relationship between bromate ion and $\mathrm{Ph}$ value in bottled water which showed a low degree of correlation. This implied that bromate content in bottled water was not influenced by the $\mathrm{Ph}$ of the samples in this study.

The same condition applied in figure 4 showing the relationship between bromate ion and $\mathrm{Ph}$ value in sachet water indicating that the effect of $\mathrm{Ph}$ was insignificant.

Table-1: Parameters used to assess cancer risk and LADD in bottled and sachet water

\begin{tabular}{|l|l|l|l|l|}
\hline Parameters & Bottled water & Sachet water & Distribution & References \\
\hline $\begin{array}{l}\text { Bromate Levels } \\
\text { (ug/I) }\end{array}$ & $4.09 \pm 0.44$ & $5.07 \pm 0.78$ & Normal & This study \\
\hline IR (I/day) & 2 & 2 & - & USEPA, 1991 \\
\hline BW (kg) & 60.7 & 60.7 & Normal & Walpole et.al 2012 \\
\hline EF (day/year) & 365 & 365 & Triangular & USEPA, 1991 \\
\hline LE (years) & 54.5 & 54.5 & - & www.worldlife Expectancy, 2015 \\
\hline
\end{tabular}

USEPA - United State, Environmental Protection Agency, EF Exposure Frequency

\section{LE - Life Expectancy}

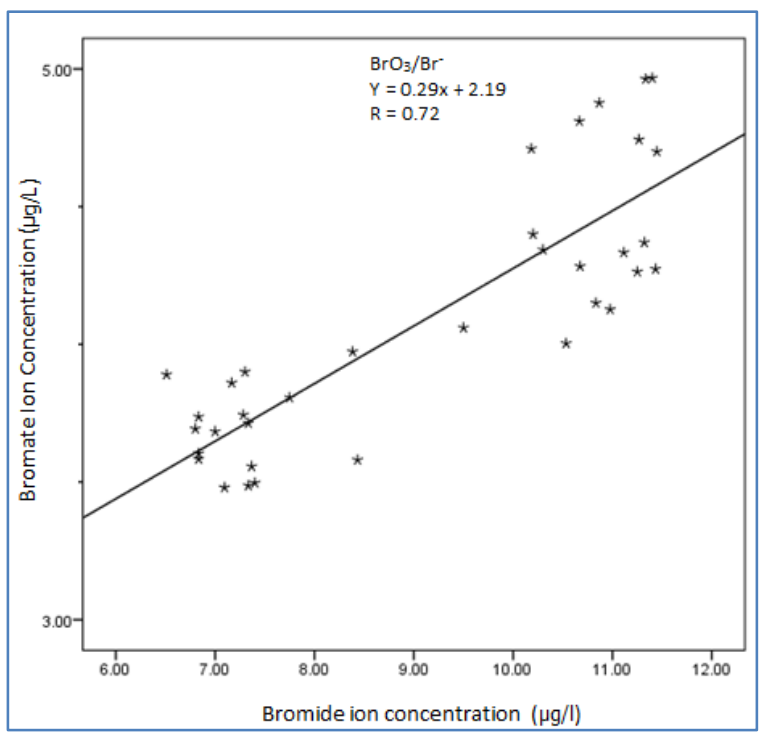

Fig-1: Scatter plot showing the relationship between Bromate and Bromide ions in bottled water



Fig-2: Scatter plot showing the relationship between bromate and Bromide ions in sachet water 
Irogbeyi, Longinus Amarachi et al; Saudi J Med Pharm Sci, Oct 2019; 5(10): 885-892

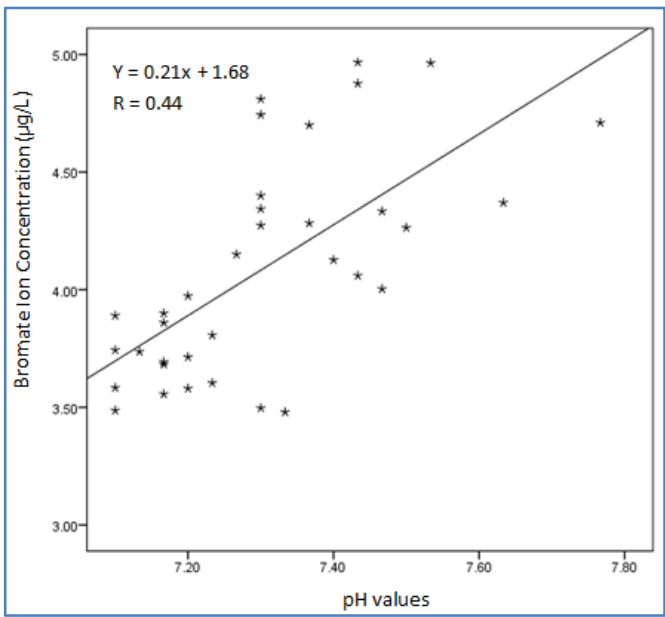

Fig-3: Scatter plot showing the relationship between Bromate and pH value in bottled water

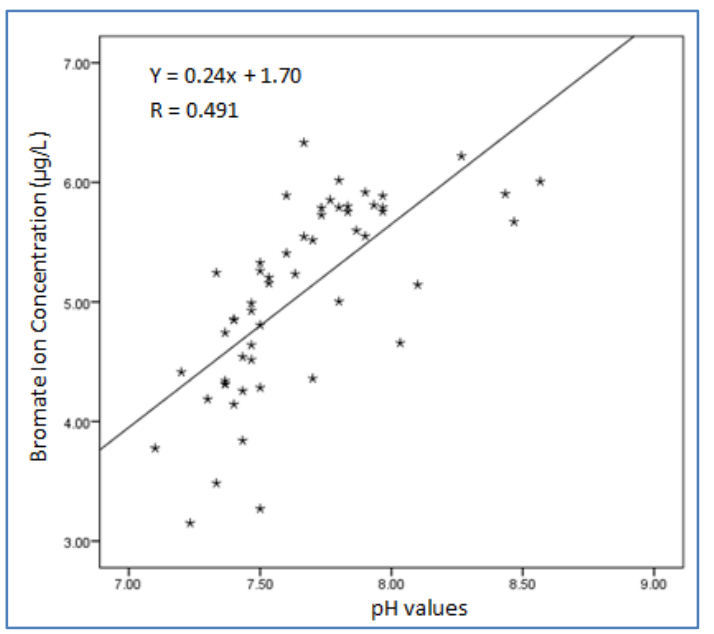

Fig-4.4: Scatter plot showing the relationship between Bromate and $\mathrm{pH}$ value in sachet water

Table-2: Showing measured Bromate, Bromide concentration, their ratios, percentage formation of bromate against predicted value and PH in bottled water of various regions of Aba metropolis and consequently risks (excess cancer risk and chemical

\begin{tabular}{|c|c|c|c|c|c|c|c|c|c|}
\hline $\begin{array}{l}\text { Bottled } \\
\text { water }\end{array}$ & Location & $\begin{array}{l}\text { Measured } \\
\text { conc, of } \mathrm{BrO}_{3^{-}} \\
(\mu \mathrm{g} / \mathrm{L})\end{array}$ & $\begin{array}{l}\text { Measured } \\
\text { conc. of } \mathrm{Br}^{-} \\
(\mu \mathrm{g} / \mathrm{L})\end{array}$ & $\begin{array}{l}\text { Measured } \\
\mathrm{BrO}_{3} \text { - con/ } \\
\text { Measured } \\
\text { Br-conc. }\end{array}$ & pH & $\begin{array}{l}\text { \% Formation } \\
\mathrm{BrO}_{3}\end{array}$ & $\begin{array}{l}\text { Cancer Risk } \\
\left(\times 10^{-4}\right)\end{array}$ & LADD & $\begin{array}{l}\text { HQ } \\
\text { (Hazard } \\
\text { quotient) }\end{array}$ \\
\hline BW-1 & Aba North & 4.70 & 11.45 & 0.41 & 7.37 & 25.66 & 0.80 & 0.148 & 0.4 \\
\hline BW-2 & & 4.33 & 11.11 & 0.39 & 7.47 & 24.36 & 0.80 & 0.137 & 0.4 \\
\hline BW-3 & & 3.89 & 6.51 & 0.60 & 7.10 & 37.35 & 0.60 & 0.122 & 0.3 \\
\hline BW-4 & & 4.71 & 10.18 & 0.46 & 7.77 & 28.92 & 0.80 & 0.149 & 0.4 \\
\hline BW-5 & & 4.26 & 11.25 & 0.38 & 7.50 & 23.67 & 0.80 & 0.135 & 0.4 \\
\hline BW-6 & & 3.48 & 7.09 & 0.49 & 7.33 & 30.68 & 0.60 & 0.110 & 0.3 \\
\hline BW-7 & & 3.69 & 6.80 & 0.54 & 7.17 & 33.92 & 0.60 & 0.117 & 0.3 \\
\hline BW-8 & & 4.37 & 11.32 & 0.39 & 7.63 & 24.13 & 0.80 & 0.138 & 0.4 \\
\hline BW-9 & & 4.96 & 11.33 & 0.44 & 7.53 & 27.36 & 0.80 & 0.157 & 0.4 \\
\hline BW-10 & & 3.81 & 7.75 & 0.49 & 7.23 & 30.73 & 0,60 & 0.120 & 0.3 \\
\hline BW-11 & & 3.97 & 8.38 & 0.47 & 7.20 & 29.61 & 0.60 & 0.125 & 0.3 \\
\hline BW-12 & & 3.50 & 7.40 & 0.47 & 7.30 & 29.56 & 0.60 & 0.111 & 0.3 \\
\hline BW-13 & & 4.74 & 11.27 & 0.42 & 7.30 & 26.29 & 0.80 & 0.150 & 0.4 \\
\hline BW-14 & & 4.27 & 11.43 & 0.37 & 7.30 & 23.35 & 0.80 & 0.135 & 0.4 \\
\hline BW-15 & & 3.60 & 6.83 & 0.53 & 7.23 & 32.94 & 0.80 & 0.114 & 0.3 \\
\hline BW-16 & Aba South & 4.06 & 9.50 & 0.43 & 7.43 & 26.71 & 0.60 & 0.128 & 0.3 \\
\hline BW-17 & & 4.81 & 10.6 & 0.45 & 7.30 & 28.17 & 0.80 & 0.152 & 0.4 \\
\hline BW-18 & & 3.58 & 8.43 & 0.42 & 7.20 & 26.54 & 0.60 & 0.113 & 0.3 \\
\hline BW-19 & & 3.90 & 7.30 & 0.53 & 7.17 & 33.39 & 0.60 & 0.123 & 0.3 \\
\hline BW-20 & & 3.74 & 6.83 & 0.55 & 7.13 & 34.22 & 0.60 & 0.118 & 0.3 \\
\hline BW-21 & & 4.13 & 10.98 & 0.38 & 7.40 & 23.51 & 0.60 & 0.130 & 0.3 \\
\hline BW-22 & & 3.56 & 7.37 & 0.48 & 7.17 & 30.19 & 0.60 & 0.112 & 0.3 \\
\hline BW-23 & & 4.00 & 10.53 & 0.38 & 7.47 & 23.74 & 0.60 & 0.126 & 0.3 \\
\hline BW-24 & & 4.88 & 10.87 & 0.45 & 7.43 & 28.06 & 0.80 & 0.154 & 0.4 \\
\hline BW-25 & & 3.86 & 7.17 & 0.54 & 7.17 & 33.65 & 0.60 & 0.122 & 0.3 \\
\hline BW-26 & Osisioma & 4.28 & 10.67 & 0.40 & 7.37 & 25.07 & 0.80 & 0.135 & 0.4 \\
\hline BW-27 & & 3.74 & 7.28 & 0.51 & 7.10 & 32.11 & 0.60 & 0.118 & 0.3 \\
\hline BW-28 & & 3.58 & 6.83 & 0.52 & 7.10 & 32.76 & 0.60 & 0.113 & 0.3 \\
\hline BW-29 & & 4.34 & 10.30 & 0.42 & 7.30 & 26.33 & 0.80 & 0.137 & 0.4 \\
\hline BW-30 & & 3.71 & 7.33 & 0.51 & 7.20 & 31.63 & 0.60 & 0.117 & 0.3 \\
\hline BW-31 & & 3.68 & 7.00 & 0.53 & 7.17 & 32.86 & 0.60 & 0.116 & 0.3 \\
\hline BW-32 & & 4.15 & 10.83 & 0.38 & 7.27 & 23.95 & 0.80 & 0.131 & 0.4 \\
\hline BW-33 & & 4.97 & 11.40 & 0.44 & 7.43 & 27.25 & 0.80 & 0.157 & 0.4 \\
\hline BW-34 & & 4.40 & 10.20 & 0.43 & 7.30 & 26.96 & 0.80 & 0.139 & 0.4 \\
\hline BW-35 & & 3.49 & 7.33 & 0.48 & 7.10 & 29.76 & 0.60 & 0.110 & 0.3 \\
\hline
\end{tabular}


Irogbeyi, Longinus Amarachi et al; Saudi J Med Pharm Sci, Oct 2019; 5(10): 885-892

Table-3: Showing measured Bromate, Bromide concentration, their ratios, percentage formation of bromate against predicted value and $\mathrm{PH}$ in sachet water of various regions of Aba metropolis and consequently risks (Cancer risk and chemical toxicity

\begin{tabular}{|c|c|c|c|c|c|c|c|c|c|}
\hline $\begin{array}{l}\text { Sachet } \\
\text { water } \\
\text { code }\end{array}$ & Locations & $\begin{array}{l}\text { Measured } \\
\text { conc. of } \\
\mathrm{BrO}_{3}^{-}(\mathrm{g} / \mathrm{L}\end{array}$ & $\begin{array}{l}\text { Measured } \\
\text { conc. Of } \\
\mathrm{Br}^{-}(\mathrm{g} / \mathrm{L}\end{array}$ & $\begin{array}{l}\text { Measured } \mathrm{BrO}_{3}^{-} \\
\text {conc./measured } \\
\mathrm{Br}^{-} \text {conc. }\end{array}$ & ph & $\begin{array}{l}\text { \% } \\
\text { formation } \\
\text { of } \mathrm{BrO}_{3}^{-}\end{array}$ & $\begin{array}{l}\text { Cancer } \\
\text { Risk } \\
(\mathbf{x 1 0}\end{array}$ & LADD & $\begin{array}{l}\text { HQ } \\
\text { Hazard }\end{array}$ \\
\hline SW-1 & Aba North & 5.16 & 10.87 & 0.47 & 7.5 & 29.67 & 0.80 & 0.163 & 0.4 \\
\hline SW-2 & & 4.74 & 10.80 & 0.44 & 7.4 & 27.43 & 0.80 & 0.150 & 0.4 \\
\hline SW-3 & & 4.19 & 9.50 & 0.44 & 7.3 & 27.57 & 0.80 & 0.132 & 0.4 \\
\hline SW-4 & & 5.52 & 11.20 & 0.49 & 7.7 & 30.80 & 1.00 & 0.174 & 0.5 \\
\hline SW-5 & & 5.89 & 11.03 & 0.53 & 7.6 & 33.37 & 1.00 & 0.186 & 0.5 \\
\hline SW-6 & & 6.33 & 12.37 & 0.51 & 7.7 & 31.98 & 1.00 & 0.200 & 0.5 \\
\hline SW-7 & & 5.79 & 11.12 & 0.52 & 7.8 & 32.54 & 1.00 & 0.183 & 0.5 \\
\hline SW-8 & & 4.66 & 11.32 & 0.41 & 8.0 & 25.73 & 0.80 & 0.147 & 0.4 \\
\hline SW-9 & & 5.67 & 11.33 & 0.50 & 8.5 & 31.28 & 1.00 & 0.179 & 0.5 \\
\hline SW-10 & & 6.01 & 11.70 & 0.51 & 8.6 & 32.10 & 1.00 & 0.190 & 0.5 \\
\hline SW-11 & & 4.26 & 8.67 & 0.49 & 7.4 & 30.71 & 0.80 & 0.135 & 0.4 \\
\hline SW-12 & & 5.80 & 11.89 & 0.49 & 7.8 & 30.49 & 1.00 & 0.183 & 0.5 \\
\hline SW-13 & & 5.55 & 11.62. & 0.48 & 7.7 & 29.85 & 1.00 & 0.175 & 0.5 \\
\hline SW-14 & & 5.79 & 11.79 & 0.49 & 8.0 & 30.69 & 1.00 & 0.183 & 0.5 \\
\hline SW-15 & & 5.92 & 11.93 & 0.50 & 7.9 & 31.01 & 1.00 & 0.187 & 0.5 \\
\hline SW-16 & & 4.34 & 9.08 & 0.48 & 7.7 & 29.87 & 0.80 & 0.137 & 0.4 \\
\hline SW-17 & & 6.22 & 12.22 & 0.50 & 8.3 & 31.81 & 1.00 & 0.197 & 0.5 \\
\hline SW-18 & & 4.81 & 9.48 & 0.51 & 7.5 & 31.71 & 0.80 & 0.152 & 0.4 \\
\hline SW-19 & & 5.60 & 12.10 & 0.46 & 7.9 & 28.93 & 1.00 & 0.177 & 0.5 \\
\hline SW-20 & & 4.54 & 9.70 & 0.47 & 7.4 & 29.25 & 0.80 & 0.143 & 0.4 \\
\hline SW-21 & & 5.41 & 11.02 & 0.49 & 7.6 & 30.68 & 1.00 & 0.171 & 0.5 \\
\hline SW-22 & & 5.79 & 11.85 & 0.49 & 7.7 & 30.54 & 1.00 & 0.183 & 0.5 \\
\hline SW-23 & & 5.21 & 10.33 & 0.50 & 7.5 & 31.52 & 0.80 & 0.165 & 0.4 \\
\hline SW-24 & & 6.02 & 11.92 & 0.51 & 7.8 & 31.56 & 1.00 & 0.190 & 0.5 \\
\hline SW-25 & & 4.93 & 10.20 & 0.48 & 7.5 & 30.21 & 0.80 & 0.156 & 0.4 \\
\hline SW-26 & Aba South & 5.73 & 11.63 & 0.49 & 7.7 & 30.79 & 1.00 & 0.181 & 0.5 \\
\hline SW-27 & & 4.86 & 9.87 & 0.49 & 7.4 & 30.78 & 0.80 & 0.154 & 0.4 \\
\hline SW-28 & & 5.89 & 11.50 & 0.51 & 8.0 & 32.01 & 1.00 & 0.186 & 0.5 \\
\hline SW-29 & & 5.76 & 11.68 & 0.49 & 7.8 & 30.82 & 1.00 & 0.182 & 0.5 \\
\hline SW-30 & & 5.24 & 10.52 & 0.50 & 7.0 & 31.13 & 0.80 & 0.166 & 0.4 \\
\hline SW-31 & & 5.86 & 11.57 & 0.51 & 7.8 & 31.66 & 1.00 & 0.185 & 0.5 \\
\hline SW-32 & & 4.32 & 9.77 & 0.44 & 7.4 & 27.64 & 0.80 & 0.136 & 0.4 \\
\hline SW-33 & & 4.99 & 10.62 & 0.47 & 7.5 & 29.37 & 0.80 & 0.158 & 0.4 \\
\hline SW-34 & & 5.33 & 11.35 & 0.47 & 7.5 & 29.35 & 1.00 & 0.168 & 0.5 \\
\hline SW-35 & & 4.41 & 10.50 . & 0.42 & 7.2 & 26.25 & 0.80 & 0.139 & 0.4 \\
\hline SW-36 & & 3.78 & 9.22 & 0.41 & 7.1 & 25.62 & 0.60 & 0.119 & 0.3 \\
\hline SW-37 & & 5.24 & 10.88 & 0.48 & 7.3 & 30.10 & 0.80 & 0.166 & 0.4 \\
\hline SW-38 & & 5.76 & 11.37 & 0.51 & 8.0 & 31.66 & 1.00 & 0.182 & 0.5 \\
\hline SW-39 & & 4.85 & 11.02 & 0.44 & 7.4 & 27.51 & 0.80 & 0.153 & 0.4 \\
\hline SW-40 & Osisioma & 5.55 & 12.13 & 0.46 & 7.9 & 28.60 & 1.00 & 0.175 & 0.5 \\
\hline SW-41 & & 5.81 & 12.28 & 0.47 & 7.9 & 29.57 & 1.00 & 0.184 & 0.5 \\
\hline SW-42 & & 4.31 & 10.42 & 0.41 & 7.4 & 25.85 & 0.80 & 0.136 & 0.4 \\
\hline SW-43 & & 4.14 & 10.00 & 0.41 & 7.4 & 25.88 & 0.80 & 0.131 & 0.4 \\
\hline SW-44 & & 5.00 & 10.33 & 0.48 & 7.8 & 30.25 & 0.80 & 0.158 & 0.4 \\
\hline SW-45 & & 3.84 & 10.05 & 0.38 & 7.4 & 23.88 & 0.60 & 0.121 & 0.3 \\
\hline SW-46 & & 4.36 & 10.57 & 0.41 & 7.7 & 25.78 & 0.80 & 0.138 & 0.4 \\
\hline SW-47 & & 5.26 & 11.42 & 0.46 & 7.5 & 28.79 & 0.80 & 0.166 & 0.4 \\
\hline SW-48 & & 3.27 & 10.13 & 0.32 & 7.5 & 20.18 & 0.60 & 0.103 & 0.3 \\
\hline SW-49 & & 5.90 & 12.08 & 0.49 & 8.4 & 30.53 & 1.00 & 0.186 & 0.5 \\
\hline SW-50 & & 4.28 & 10.50 & 0.41 & 7.5 & 25.48 & 0.80 & 0.135 & 0.4 \\
\hline SW-51 & & 4.64 & 10.08 & 0.44 & 7.5 & 28.77 & 0.80 & 0.147 & 0.4 \\
\hline SW-52 & & 5.14 & 11.88 & 0.43 & 8.1 & 27.64 & 0.80 & 0.162 & 0.4 \\
\hline SW-53 & & 3.48 & 9.25 & 0.38 & 7.3 & 23.51 & 0.60 & 0.110 & 0.3 \\
\hline SW-54 & & 3.15 & 8.20 & 0.38 & 7.2 & 24.00 & 0.60 & 0.100 & 0.3 \\
\hline SW-55 & & 4.52 & 10.73 & 0.42 & 7.5 & 26.33 & 0.80 & 0.143 & 0.4 \\
\hline
\end{tabular}


Irogbeyi, Longinus Amarachi et al; Saudi J Med Pharm Sci, Oct 2019; 5(10): 885-892

\section{Risk Assessment due to Oral Ingestion of Bromate in Bottled and Sachet Water}

The individual excess cancer risk due to ingestion of bromate in bottled and sachet water at an average of $2 \mathrm{~L} /$ day over the lifetime expectancy of 54.5 years for a Nigerian adult was observed to be in the range of $6 \times 10^{-5}-7 \times 10^{-5}$ with mean value of $6.91 \times 10^{-5}$ and mean value of $9.0 \times 10^{-5}$ in the range of $6.0 \times 10^{-5}-$ $1.0 \times 10^{-4}$ respectively. The values showed about one order of magnitude lower than the mean value of $2.24 \times 10^{-4}$ found in Indian bottled water [16]. All the values were higher than the maximum acceptable level $\left(2 \times 10^{-5}\right)$ as per guidelines of USEPA [26]. This implied that people in this region were exposed to high cancer risk resulting from the overtime ingestion of bromate in bottled and sachet water. The sachet water, however, has more risk assessment than the bottled water from the values found in this study. Evaluation of chemical toxicity risk through bottled and sachet water ingestion produced hazard quotient (HQ) values of 0.35 and 0.43 respectively derived from the mean LADD of 0.129 in bottled water and the mean LADD of 0.160 in sachet water compared with the reference dose (RfD) of $0.372 \mu \mathrm{g} / \mathrm{kg} /$ day shown in table $[2,3]$. The values were found to be lower than the value of 1.01 found in Indian bottled water [16]. In accordance with the standard EPA method, if the HQ exceeds one, there is a chance that non-carcinogenic effects may occur with the probability which tends to increase as the HQ increases [27]. It therefore showed from this study that people in this region were safe from the chemical toxicity risk assessment point of view.

\section{CONCLUSION}

This study was carried out to assess the health risk involved in drinking bottled and sachet water treated with ozone as a means of water purification in Aba metropolis, Nigeria. It was realised that a carcinogenic substance bromate formed as a disinfection bye - product depends to a large extent on the level of bromide present and ozone dose. This underlined the importance of the central water regulatory authority in the country to set up standard measures that will reduce the effects of such factors like bromide, $\mathrm{Ph}$, temperature and ozone dose which lead to bromate formation above the acceptable level.

\section{Limitation of Study}

The study did not involve the use of high technology equipments such as ion chromatography for more accurate and reliable results.

\section{ACKNOWLEDGMENT}

The authors are grateful to Mrs. Francisca U. Irogbeyi and Mr. Innocent Ikpeama for their technical assistance.

\section{Conflict of Interest}

The authors declare no conflict of interest in the course of conducting this study.

\section{REFERENCES}

1. Thompson, T., Fawell, J., Kunikane, S., Jackson, D., Appleyard, S., Callan, P., ... \& World Health Organization. (2007). Chemical safety of drinking water: assessing priorities for risk management.

2. Egwari, L., \& Aboaba, O. O. (2002). Environmental impact on the bacteriological quality of domestic water supplies in Lagos, Nigeria. Revista de Saúde Pública, 36, 513-520.

3. Cotrubo, J. G. M., Jackson, P., Magara, Y., \& Ohanian, E. (2005). Bromate in Drinking-Water, Background Document for Development of WHO Guidelines for Drinking-Water Quality. World Health Organization, Geneva, Switzerland.

4. Fawell, J., \& Walker, M. (2006). Approaches to determining regulatory values for carcinogens with particular reference to bromate. Toxicology, 221(2-3), 149-153.

5. Weinberg, H. S., Delcomyn, C. A., \& Unnam, V. (2003). Bromate in chlorinated drinking waters: occurrence and implications for future regulation. Environmental science \& technology, 37(14), 3104-3110.

6. Amy, G., Douville, C., Daw, B., Sohn, J., Galey, C., Gatel, D., \& Cavard, J. (2000). Bromate formation under ozonation conditions to inactivate Cryptosporidium. Water science and technology, 41(7), 61-66.

7. Center for Food Safety, \& Applied Nutrition (US). (2004). The bad bug book: foodborne pathogenic microorganisms and natural toxins handbook. International Medical Pub.

8. U.S. EPA. (2006). Disinfection Byproduct Information. Information Collection Rule, Office of Ground Water and Drinking Water. U.S. Environmental Protection Agency, Washington, DC. Accessed at: http://www.epa.gov/enviro/html/icr/dbp.html. 2006

9. Macalady, D. L., Carpenter, J. H., \& Moore, C. A. (1977). Sunlight-induced bromate formation in chlorinated seawater. Science, 195(4284), 1335-1337.

10. U.S. EPA. (1998). National primary drinking water regulations: Disinfectants and disinfection by-products. Federal Register, 63(241):6940511 .

11. European Parliament and Council Directive No. 2003/40/EC, Establishing the List, Concentration Limits and Labeling Requirements for the Constituents of Natural Mineral Waters and the Conditions for Using Ozone-Enriched Air for the 
Treatment of Natural Mineral Waters and Spring Waters, 2003.

12. Hoigné, J., \& Bader, H. (1994). Kinetics of reactions of chlorine dioxide $(\mathrm{OClO})$ in water- $\mathrm{I}$. Rate constants for inorganic and organic compounds. Water Research, 28(1), 45-55.

13. US EPA.(1999). Guidelines for Carcinogen Risk Assessment, US Environmental Protection Agency, Federal Register, 51(185), 33992-34003.

14. Amy, G., Bull, R., Craun, G. F., Pegram, R. A., Siddiqui, M., \& World Health Organization. (2000). Disinfectants and disinfectant byproducts.

15. Kurokawa, Y., Aoki, S., Matsushima, Y., Takamura, N., Imazawa, T., \& Hayashi, Y. (1986). Dose-response studies on the carcinogenicity of potassium bromate in F344 rats after long-term oral administration. Journal of the National Cancer Institute, 77(4), 977-982.

16. Kumar, A., Rout, S., \& Singhal, R. K. (2011). Health Risk Assessment for Bromate (Bro3-) Traces in Ozonated Indian Bottled Water. Journal of Environmental Protection, 2(05), 571.

17. Romele, L. (1998). Spectrophotometric determination of low levels of bromate in drinking water after reaction with fuchsin. Analyst, 123(2), 291-294.

18. United States. Environmental Protection Agency. Office of Ground Water, \& Drinking Water. (2000). Preliminary Health Risk Reduction and Cost Analysis: Revised National Primary Drinking Water Standards for Radionuclides. US Environmental Protection Agency.

19. World Health Organization. (1998). Guidelines for drinking-water quality. Vol. 2, Health criteria and other supporting information: addendum (No. WHO/EOS/98.1). World Health Organization.

20. Health Canada Summary of Guidelines for Canadian Drinking Water Quality, FederalProvincial Subcommittee on Drinking Water of the Federal Provincial-Territorial Committee on Environmental and Occupational health, Ottawa, Ontario, Canada.1999

21. US EPA. (1991). EPA Standard Default Exposure Factors, Washington DC.

22. WWW.Worldlife expectancy.(2015). Com/nigeria life-expectancy.

23. Walpole, S. C., Prieto-Merino, D., Edwards, P., Cleland, J., Stevens, G., \& Roberts, I. (2012). The weight of nations: an estimation of adult human biomass. BMC public health, 12(1), 439.

24. McGuire, M. J., Krasner, S. W., \& Gramith, J. T. (1990). Comments on bromide levels in state project water and impacts on control of disinfectant by-products. Los Angeles, CA, Metropolitan Walter District of Southern California.

25. Haag, W. R., \& Hoigne, J. (1983). Ozonation of bromide-containing waters: kinetics of formation of hypobromous acid and bromate. Environmental Science \& Technology, 17(5), 261-267.

26. U.S. Environmental Protection Agency. Epa's report on the environment Draft. (2003). U.S. Environmental Protection Agency, Washington, DC, 2008.

27. U.S.E.P.A. Region 9, Preliminary Remediation Goals.

$<$ http://www.epa.Gov/region09/waste/sfund/pr g>.2002 